\title{
First record of cleaning by a triplefin blenny in the Tropical Pacific
}

Received: 23 April 2010/Accepted: 17 June 2010/Published online: 11 July 2010

(C) Springer-Verlag 2010

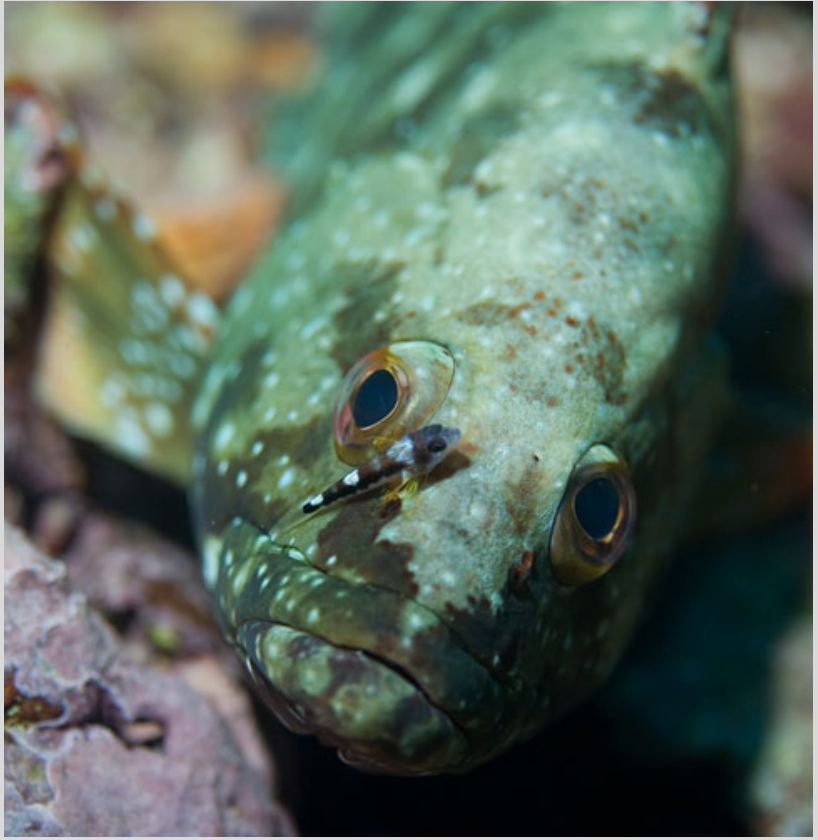

Fig. 1 The triplefin blenny Lepidonetes bimaculatus ( $\sim \mathrm{cm}$ total length) inspects the snout of the grouper Epinephelus labriformis, which poses on a rocky reef at $12-\mathrm{m}$ depth at Malpelo Island, off Colombia
Cleaning symbiosis between fishes is an interspecific interaction in which a fish (the cleaner) seeks food on the body surface of other fishes (the clients) which, in turn, become free of parasites and debris (Côté 2000). About 110 reef fish species in 21 families are known as cleaners (Côté 2000), and no doubt this figure will increase with additional field studies.

Here, we report for the first time cleaning by a triplefin blenny (Tripterygiidae) in the Tropical Eastern Pacific. An endemic to Malpelo Island, the twin-spot triplefin, Lepidonetes bimaculatus was observed cleaning the starry grouper, Epinephelus labriformis (Fig. 1) in August 2009 and February 2010. The cleaning interactions $(n=10)$ were always initiated by the cleaner, which moved slowly towards and climbed on the client, which posed almost motionless on the reef. The snout and dorsal fin of the clients were the most inspected body parts, at which the blenny occasionally pounced. All interactions lasted 1-2 min.

Species of Tripterygiidae feed mostly on small benthic invertebrates (Feary et al. 2009), but three species from coastal New Zealand (temperate South Western Pacific) were observed cleaning: Notoclinops segmentatus, $N$. caerulepunctus, and Forsterygion lapillum (Clements 2003).

Acknowledgments We thank the Colombian System of National Natural Parks, the Malpelo Foundation, Conservation International, Walton Family Foundation and Fondo para la Acción Ambiental y la Niñez for the opportunity and funds for research at Malpelo's Sanctuary of Flora and Fauna, and A. Grutter and K. Clements for information on New Zealand triplefins.

\section{References}

Clements KD (2003) Triplefins. In: Andrew NL, Francis MP (eds) The living reef. The ecology of New Zealand's rocky reefs. Craig Potton Publishing, Nelson, pp 160-167

Côté IM (2000) Evolution and ecology of cleaning symbiosis in the sea. Oceanogr Mar Biol Annu Rev 38:311-355

Feary DA, Wellenreuther M, Clements KD (2009) Trophic ecology of New Zealand triplefin fishes (Family Tripterygiidae). Mar Biol 156:1703-1714

\section{J. P. Quimbayo ( $\bowtie)$}

Grupo de investigación en ecología de arrecifes coralinos, Universidad del Valle, Apartado Aéreo 25360, Cali, Colombia e-mail: jupaquia@gmail.com

\section{J. P. Quimbayo · S. R. Floeter}

Departamento de Ecologia e Zoologia, Universidade Federal de Santa Catarina, 88010-970 Florianópolis, SC, Brazil

F. A. Zapata

Departamento de Biología, Universidad del Valle, Apartado Aéreo 25360 Cali, Colombia

S. Bessudo

Fundación Malpelo y otros Ecosistemas Marinos, Carrera 11 No. 87-51, Local 4, Bogotá, Colombia

I. Sazima

Museu de Zoologia, Universidade Estadual de Campinas, Caixa Postal 6109, 13083-970 Campinas, São Paulo, Brazil

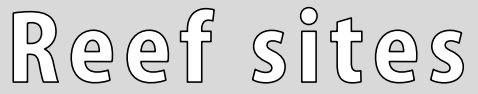

Coral Reefs (2010) 29:909

DOI $10.1007 / \mathrm{s} 00338-010-0656-8$ 